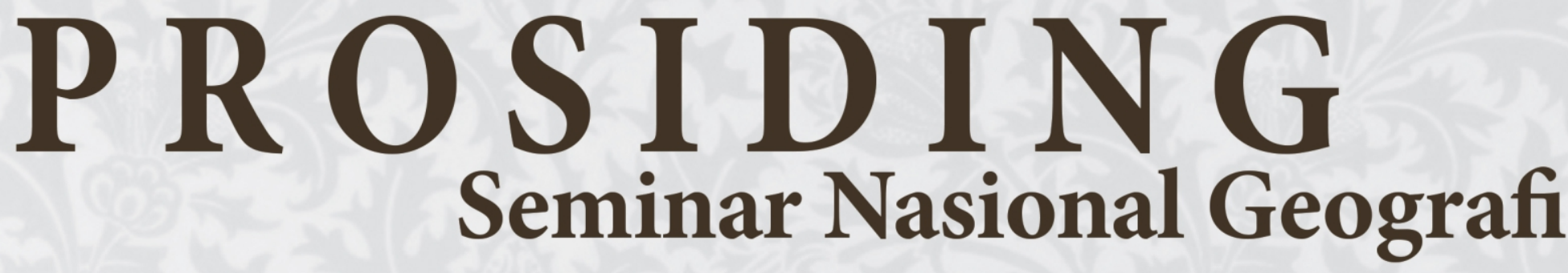

Peran Geografi Dalam Pengelolaan Sumberdaya Wilayah NKRI di Era Teknologi 18 November 2017 - Universitas Gadjah Mada

\title{
Diselenggarakan Oleh
}

Panitia Seminar Nasional Geografi Tahun 2017 Himpunan Mahasiswa Program Pascasarjana Geografi Fakultas Geografi Universitas Gadjah Mada

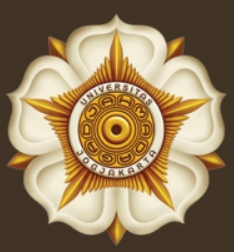




\section{SEMINAR NASIONAL \\ GEOGRAFI}

PROSIDING

PERAN GEOGRAFI DALAM PENGELOLAAN SUMBERDAYA WILAYAH NKRI DI ERA TEKNOLOGI

18 November 2017

Fakultas Geografi UGM, Yogyakarta

BADAN PENERBIT FAKULTAS GEOGRAFI

UNIVERSITAS GADJAH MADA 


\section{PROSIDING}

SEMINAR NASIONAL GEOGRAFI 2017

PERAN GEOGRAFI DALAM PENGELOLAAN SUMBERDAYA WILAYAH NKRI DI

ERA TEKNOLOGI

Program Studi Pascasarjana Geografi, Fakultas Geografi

Universitas Gadjah Mada, Yogyakarta, Indonesia

Penanggung Jawab

Ketua Pelaksana

Reviewer

Ketua Panitia Acara

Wakil Ketua Panitia Acara

Desain Sampul

Editor dan Tata Letak

ISBN

Cetakan pertama
: Dr. Lutfi Muta'ali, S.Si., M.T.

: Imam Arifa'illah Syaiful Huda

: Dr. Lutfi Muta'ali, S.Si., M.T.

Dr. Sudrajat, S.Si., M.P.

Dr. Nurul Khakhim, M.Si.

Dr. Sri Rum Giyarsih, M.Si.

Emilya Nurjani, S.Si., M.Si.

: Zaidan Zikri Malem

: Ramlah

: Rifki Randa Syafri

: Aprilia Riszi Indah Dewi Shara

Armandha Redo Pratama

Diana Barirotuttaqiyyah

Iesyat Fatimah

Indira Chairunnisa

Ringga Pridiatama

Riyan Alaji

: 978-979-8786-78-5

: Pertama, Maret 2018

\section{Dipublikasikan oleh:}

Badan Penerbit Fakultas Geografi, Universitas Gadjah Mada

Sekip Utara, Jalan Kliurang, Bulaksumur, Yogyakarta 55281

Telpon +62 274649 2340, +62 274589595

Email: bpfg.geo@ugm.ac.id

Website: www.geo.ugm.ac.id 


\section{KATA PENGANTAR}

Puji syukur kepada Allah SWT dan shalawat serta salam selalu tercurahkan kepada Rasulullah SAW. Berkat limpahan dan rahmat-Nya acara Seminar Nasional Geografi 2017 dapat terlaksana.

Acara ini merupakan acara yang diselenggarakan oleh Himpunan Mahasiswa Program Pascasarjana Geografi, Fakultas Geografi, Universitas Gadjah Mada. Tema yang dipilih yaitu mengenai "Peran Geografi dalam Pengelolaan Sumberdaya Wilayah NKRI di Era Teknologi". Indonesia memiliki kekayaan sumberdaya alam yang besar. Namun kekayaan alam yang dimiliki Indonesia tidak mencerminkan kesejahteraan masyarakat. Hal ini menunjukkan bahwa diperlukannya evaluasi dalam pemanfaatan sumberdaya alam untuk menunjang kesejahteraan masyarakat. Penerapan prinsip-prinsip pembangunan berkelanjutan dalam pengelolaan sumberdaya wilayah menjadi sebuah keniscayaan dalam upaya pemerataan pembangunan, penghematan energi, pelestarian lingkungan, pembangunan ekonomi, dan pengembangan sumberdaya manusia yang melibatkan peran serta masyarakat dalam proses pembangunan secara terpadu. Kemajuan teknologi dalam bidang informasi dan komunikasi dapat digunakan untuk mengoptimalkan pembangunan perekonomian berbasis sumberdaya alam sebagai penggerak kemajuan dan kemakmuran bangsa. Berangkat dari pemikiran tersebut, Himpunan Mahasiswa Program Pascasarjana Geografi, Fakultas Geografi, Universitas Gadjah Mada bermaksud menyelenggarakan seminar nasional. Kegiatan seminar ini diharapkan dapat menjadi ajang komunikasi antar mahasiswa, peneliti, para ahli, dan akademisi di Indonesia, sehingga didapatkan pemahaman yang sama tentang pengelolaan sumberdaya wilayah yang terpadu dan berkelanjutan kemudian ditindaklanjuti dalam bentuk penelitian dan pengabdian pada masyarakat yang berkualitas, dan memiliki daya guna untuk menunjang pengelolaan sumberdaya wilayah yang terpadu, optimal, dan berkelanjutan.

Acara ini tidak dapat terselenggara apabila tidak ada kerjasama dari berbagai pihak.

Oleh karena itu, kami mengucapkan terimakasih kepada berbagai pihak yang telah berkontribusi untuk acara Seminar Nasional Geografi 2017.

Yogyakarta, Maret 2018

Imam Arifaillah Syaiful Huda

Ketua Panitia Seminar Nasional Geografi 2017 


\section{DAFTAR ISI}

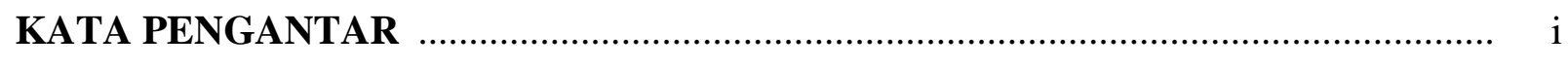

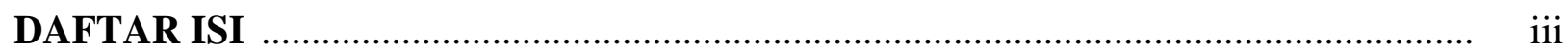

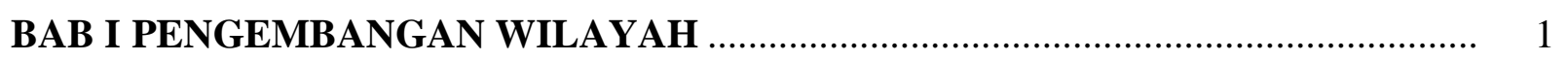

1.1 Analisis Konsentrasi Geografis Industri Mikro dan Kecil (IMK) di Indonesia

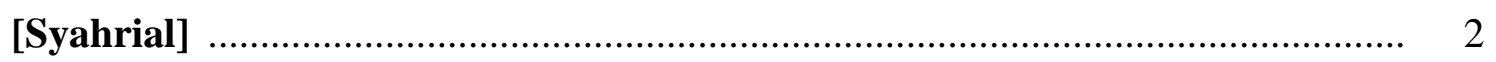

1.2 Analisis Struktur Ruang untuk Menentukan Pusat Perkembangan Wilayah di Kabupaten Banyumas

[Melly Heidy Suwargany, dkk]

1.3 Hubungan IPM dengan Kemiskinan di Provinsi Jawa Tengah (Tahun 2010 - 2016)

[Yetti A.S. dan Ringga P.]

1.4 Hubungan Kesesuaian Rekayasa Shelter dengan Arus Lalu Lintas dan Tingkat Partisipasi Pengguna Shelter

[Armandha R. P., dkk]

1.5 Optimalisasi dan Inventarisasi Pengelolaan Potensi Wisata Alam Sebagai Wilayah Pertumbuhan Ekonomi Baru dalam Upaya Menjaga Keutuhan NKRI di Perbatasan Kalimantan Barat - Sarawak Malaysia

[ Imanuddin ].

1.6 Peremajaan Permukiman Kumuh dengan Penerapan Konsep Ecovillage

[Wardana W. dan Fitri N. I. S.]

1.7 Perencanaan Tata Ruang Berbasis Komunitas Lokal dalam Upaya Pengurangan Resiko Bencana Tsunami

[Mirza Desfandi]

1.8 Perkembangan Sungai dan Pemukiman Kota Surabaya Abad 19 dan 20: Banjir dan Penataan Kota dalam Kajian Sejarah Komparatif

[Subandi Rianto].

1.9 Persebaran Ruko Terbengkalai dan Pertimbangan Investasi Ruko di Kota Pontianak [Galuh B., Dian E., dan Agus S.] 
1.10 Perspektif Multidisiplin Tentang Ruang dan Implikasinya Dalam Teknologi Pengembangan Wilayah

[Wulansari, dkk.]

1.11 Pola Spasial Disparitas antar Wilayah di Provinsi Sumatera Barat

[Selvi Elvina]

1.12 Regionalisasi Sektor Unggulan untuk Peningkatan Perekonomian dan Pembangunan Wilayah di Propinsi Daerah Istimewa Yogyakarta

[Lutfi Muta'ali]

1.13 Tinjauan Kritis Terhadap Wacana Pembangunan Kereta Gantung Rinjani dalam Perspektif Masyarakat Resiko

[Rifki M. I. T., Rizal M. S., dan Azhari E.]

BAB II FISIK

2.1 Abrasi Pantai Kuwaru: Persepsi Wisatawan Terhadap Ancaman Abrasi

[Agustina Setyaningrum dan Sutanto Trijuni Putro]

2.2 Analisis Kekritisan Meteorologis Daerah Aliran Sungai Kokok Sambelia, Lombok Timur, Nusa Tenggara Barat

[M. Y. Widasmara, dkk.]

2.3 Analisis Spasial Perubahan Penggunaan Lahan Terhadap Kesesuaian Kawasan Resapan Air (Studi Kasus Kota Kendari)

[Jufri Karim, dkk.]

2.4 Analisis Status Hara Tanah pada Lahan Persiapan Percetakan Sawah di Kabupaten Bombana

[Hasbullah Syaf, dkk.]

2.5 Deteksi Potensi Degradasi Lahan Berbasis Integrasi Erosi dan Longsorlahan di Hulu DAS Tondano

[Murdiyanto dan Sri Sulastriningsih]

2.6 Geomorfologi dan Peranannya dalam Mitigasi Bencana Alam di Indonesia [Gregorius Agung Malik] 
2.7 Hidrodinamika Mataair Ditinjau dari Karakteristik Aliran dan Kualitas Air (Studi : Mataair Ngrunggung, Kecamatan Playen, Kabupaten Gunungkidul)

[M. Widyastuti, dkk.]

2.8 Hutan Kota Tibang Sebagai Upaya Mengatasi Masalah Hidrologi di Kota Banda Aceh

[Nanda S., Emtizal S., dan Aulia R.] 205

2.9 Kajian Kestabilan Lereng dan Kriteria Penggalian pada Tambang Batupasir Formasi Pulaubalang

[Ashabul Kahfi].

2.10 Kajian Stabilitas Lereng Kawasan Kawah Gunung Kelud sebagai Efek Rehabilitasi Terowongan Ampera

[Rokhmat Hidayat dan Dwi Kristianto] 230

2.11 Karakteristik Beban Pencemar di Sungai Code sebagai Fungsi Penggunaan Lahan Terbangun

[M.P. Hadi dan M.Y. Widasmara]

2.12 Mengatasi Bencana Alam Banjir dan Peluang Restorasi Sungai (Studi Kasus: Wilayah Sukoaharjo)

[Jaka Suryanta]

2.13 Normal Curah Hujan Kepulauan Bangka Belitung Berbasis Data Climate Hazards Group Infra-Red Precipitation with Stations (CHIRPS)

[Akhmad F. dan Rizki A.]

2.14 Pengaruh Infrastruktur Terhadap Pertumbuhan Ekonomi Indonesia [Asti Rumiatun]

2.15 Pengelolaan Mataair Banyu Dal Berbasis Masyarakat untuk Kebutuhan Domestik dan Irigasi di Desa Ngranget, Kecamatan Dagangan, Kabupaten Madiun (Sebagai Sumber Belajar XI SMA)

[Erva S., Puguh K., dan Gamal R.]

2.16 Teknologi Konservasi untuk Penanganan Kawasan Resapan Air di Daerah Kawasan Lindung

[Nurheny Aji Pawestri] 
3.1 Analisis Faktor - Faktor Penyebab Keluarga Pra Sejahtera di Kecamatan Sawahan Kabupaten Madiun

[Rama Dwi Setiyo Kuncoro]

3.2 Eksistensi Penjual Kupang Keliling Di Kota Surabaya

[M. Fikri Amrullah]

302

3.3 Faktor Penarik dan Pendorong Mobilitas Penduduk Ulang Alik di Wilayah Peri Urban Tasikmalaya

[Elgar Balasa Singkawijaya]

308

3.4 Kapasitas dan Persepsi Stakeholder dalam Pengelolaan Ekowisata Berbasis Kehutanan di Petungkriyono, Jawa Tengah

[Dila Swestiani]

3.5 Kearifan Lokal Kekerik Sebagai Upaya Menekan Laju Pertumbuhan Penduduk Suku Tengger Ngadisari Probolinggo

[Danang A., Ahmad H. P., dan Agnes C. M.]

3.6 Kondisi Masyarakat Korban Bencana Gerakan Tanah di Kecamatan Malausma Kabupaten Majalengka

[Wiwin Widiawati dan Ramona Indriani]

3.7 Modal Sosial Masyarakat Kampung Sewu dalam Mitigasi Bencana Banjir Sungai Bengawan Solo

[Annisa N. D., Argyo D., dan Drajat T. K.]

3.8 Nilai-nilai Budaya dalam Upacara Adat Manyanggar pada Suku Dayak Ngaju di Kalimantan Tengah

[Neni Puji Nur Rahmawati]

3.9 Pengaruh Lingkungan dalam Karakteristik Corak Batik Tasik Sebagai Ekonomi Kreatif

[Tresa T. S. dan Rasi Y. M.]

3.10 Pengurangan Risiko Bencana Banjir Secara Berkelanjutan Melalui Program Community Flood Resilience (CFR) di Kota Surakarta

[Dani B. M., Bagus H., dan Ahmad Z.] 
3.11 Peran Masyarakat dan Pemerintah dalam Upaya Mempertahankan Eksistensi Telaga Cebong

[Aprilia E. D. dan Evi M. K.]

3.12 Perubahan Sosial Masyarakat di Sektor Pariwisata Kawasan Kaliadem Pasca Erupsi Gunung Merapi Tahun 2010

[Anisa E. P., Titis P. D., dan Dina R.]

3.13 Prospek Budidaya Bambu Petung Dendrocalamus asper (Schult.) Backer ex Heyne di Hutan Rakyat Desa Batur Tengah, Kecamatan Kintamani, Kabupaten Bangli, Provinsi Bali

[Aris Sudomo]

3.14 Strategi Adaptasi Masyarakat Kawasan Karst dalam Mengatasi Bencana Kekeringan di Kecamatan Saptosari, Gunungkidul

[Iesyat Fathimah, dkk.]

3.15 Tingkat Partisipasi PKK (Pemberdayaan Kesejahteraan Keluarga) dalam Pengelolaan Sampah di Dusun Kadilobo, Desa Purwobinangun, Kecamatan Pakem, Kabupaten Sleman

[Pebri Nurhayati]

\section{BAB IV PARIWISATA}

4.1 Analisis Komponen Daya Tarik Wisata di Desa Wisata Krebet dan Desa Wisata Bobung, Daerah Istimewa Yogyakarta

[Dyah Widiyastut, dkk.]

4.2 Analisis Rantai Nilai Kerajinan Batik Kayu di Desa Wisata Krebet

[Heni Ermawati, Lilik Andriyani, dan Dyah Widiyastuti]

4.3 Ekowisata Sebagai Upaya Pengelolaan Pariwisata Berkelanjutan (Studi Kasus Desa Wisata Pancoh, Girikerto, Turi, Sleman)

[Sulis Purwanto]

4.4 Identifikasi Lahan Potensial untuk Pengembangan Pariwisata di Kabupaten Buton Selatan

[Djafar Mey, dkk.] 
4.5 Kajian Bangunan Bersejarah Mesjid Al-Mashun Kota Medan di Nilai Dari Historis dan Estetika

[Wahyu Hidayat dan Tunggul H. Ganie]

4.6 Karakterisasi Tourism Business District (TBD) Di Kota Tangerang, Banten

[Muhammad Zid, Cahyadi S., dan Dea Miftah S.]

4.7 Karakteristik Usaha Kerajinan Batik Kayu di Desa Wisata Krebet, Kecamatan Pajangan, Bantul, Yogyakarta

[Tyas Fitri K., Husna Zaiti A., dan Dyah Widiyastuti].

4.8 Pemanfaatan Jaringan Sosial dalam Pengembangan Pariwisata Berbasis Sumber Daya Wilayah di Daerah Rawan Longsor

[Titis Puspita D., Dina Ruslanjari, dan Muhamad]

4.9 Pengelolaan Hutan Kemasyarakatan sebagai Wisata Alam di Dusun Kalibiru, Desa Hargowilis, Kecamatan Kokap

[Yuli Astuti]

4.10 Pengelolaan Kawasan Taman Nasional Komodo di Kecamatan Komodo Kabupaten Manggarai Barat

[Liviana Sardina Darciani, dkk.]

4.11 Pengelolaan Pulau Kecil untuk Pariwisata (Studi Kasus Pulau Enggano, Bengkulu Utara)

[Aulia Rahmawati1, Nanda Satria, dan Emtizal Saprodi]

4.12 Pengembangan Desa Wisata Berbasis Agrowisata di Desa Pancasari Kabupaten Buleleng

[Isty Bunga Herliani, dkk.]

4.13 Peningkatan Kegiatan Ekonomi dan Pariwisata di Balai Ekonomi Desa Kawasan Wiasata Borobudur, Kabupaten Magelang, Jawa Tengah

[Afrinia L. P. dan Ika A. S.]

4.14 Potensi Kampung Adat Cireundeu Sebagai Penghasil Olahan Singkong [Miftah Hidayat]

4.15 Studi Potensi Geowisata Menara Karst Fatule’u, Kabupaten Kupang, Nusa Tenggara Timur

[Albert S. A. I. Telnoni dan Ardhan Ismail] 555 
4.16 Tingkat Kepuasan Wisatawan Domestik dan Mancanegara Terhadap Cinderamata Khas Aceh di Kota Banda Aceh

[Cut T. T., Maulida R., dan Ahmad H.]

BAB V MULTIDISIPLIN DAN MARITIM

5.1 Analisis Soal Pada Buku Teks Geografi SMA Kelas XII untuk Mendukung Berpikir Keruangan

[Pragita Dyah Ambarwati]

5.2 Kesiapsiagaan Masyarakat Pesisir di Kecamatan Saptosari Kabupaten Gunungkidul dalam Menghadapi Bencana

[Bayu Bima Yusufa, dkk.].

5.3 Partisipasi Masyarakat dalam Menjaga Ekosistem Laut Wilayah Taman Nasional Wakatobi

[Surdin, dkk.]

5.4 Pemanfaatan Sistem Informasi Geografis untuk Pemetaan Risiko Bencana Gunungapi dari Aspek Sosial di Kabupaten Sleman

[Haikal Muhammad Ihsan, dkk.]

5.5 Pembangunan Keterbelakangan Wilayah Pesisir - pak nurul

[Putu Indra Christiawan]

5.6 Pendidikan Konservasi Sebagai Upaya dalam Pengelolaan Sumberdaya Alam di Indonesia

[David Rizaldy]

5.7 Pengembangan Teknologi Alat Tangkap Ikan Ramah Lingkungan pada Nelayan Pengguna Cantrang di Pantai Pelabuhan Perikanan Kab. Batang Jawa Tengah (Suatu Kajian Geografi Sosial dalam Perspektif Sosiologi Konstruksi Teknologi) [Marini Kristina Situmeang]

5.8 Pengintegrasian Kearifan Lokal Subak dalam Pembelajaran Geografi

[Ida B. W. W. dan Aprilia R. I. D. S.] 
5.9 Penyusunan Komik Materi Dampak Penambangan Karst di Bedoyo, Kecamatan Ponjong, Gunung Kidul Terhadap Ekosistem Gua untuk Menanamkan Nilai Peduli Lingkungan Siswa SMA Kelas X Semester Genap

[Ika F. S., Tien A., dan Triatmanto]

5.10 Peran Pendidikan Geografi dalam Mewujudkan Pembangunan Berkelanjutan (Education For Sustainable Development)

[Abdul W. A. dan M. Hafizul F.]

5.11 Peran Pendidikan Geografi untuk Mitigasi Bencana Gunung Api Anak Krakatau Selat Sunda

[Emtizal S., Aulia R., dan Nanda S.]

5.12 Potensi Usaha Peternakan Sapi Potong di Kecamatan Cikancung Kabupaten Bandung

[Rohdian Histiyadi]

5.13 Serangan Penyakit Embun Tepung (Powdery Mildew) pada Tiga Provenan Jamblang (Syzygium Cumini L.Skeels)

[Benyamin D. dan Aris S.]

5.14 Strategi Pengelolaan Sumberdaya Pesisir di Kabupaten Buleleng

[I Putu Ananda Citra] 694

5.15 Tingkat Spatial Literacy Siswa Kelas XI dalam Mendukung Pengetahuan Dasar Kebencanaan Pada Wilayah Rawan Bencana di Malang Selatan

[Nestia A. P., I. Komang A., dam Syamsul B.] 703

5.16 Uji Banding Pemijahan Masal Rainbow Merah Perot (Glossolepis Incisus) dengan Rainbow Merah Normal di Akuarium

[Tutik Kadarini]

BAB VI PEMBANGUNAN WILAYAH DAN SOSIAL

6.1 Analisis Daya Dukung Lahan untuk Kebutuhan Permukiman Kabupaten Deli Serdang Tahun 2035

[Muhammad Farouq Ghazali Matondang]

6.2 Analisis Pemanfaatan Ruang Berdasarkan Qanun No 4 Tentang Rtrw Di Kota Banda Aceh 
[H. Daska Aziz dan M. Hafizul Furqan]

6.3 Evaluasi Potensi Peternakan (Sapi Potong) Di Kabupaten Timor Tengah Selatan [Jendri Abimelek Nenobais] 736

6.4 Evaluasi Tata Ruang Pesisir Terhadap Bencana Abrasi di Kabupaten Jepara

[Akli S. N., Arief W., dan Irvan A. K.]

6.5 Indeks Perkembangan Wilayah Kabupaten dan Kota di Propinsi Jawa Timur [Rama Dwi Setiyo Kuncoro dan Ulul Albab]

6.6 Perubahan Aset Manusian (Human Capital) Rumah Tangga Terdampak Pengembangan Bandara Kulonprogo Yogyakarta

[Benny Natalina Sihombing].

6.7 Pola Migrasi Internasional Tenaga Kerja Indonesia (TKI) Asal Kecamatan Kawunganten Kabupaten Cilacap Tahun 2016

[Riyan Alaji1, Sugiyanto, dan Wakino]

6.8 Profil Kemiskinan Wanita Usia Subur di Kalimantan Selatan (Analisis Data Survei Demografi dan Kesehatan Indonesia Tahun 2012)

[Norma Yuni Kartika]

6.9 Resistensi Budaya Kawin Anom Suku Banjar: Karakteristik Usia Perkawinan Pertama Perempuan

[Norma Y. K., Muhajir D., dan Sukamdi]

6.10 Tipologi Wilayah Perbatasan: Memahami Karakteristik Wilayah Perbatasan Negara Indonesia Berdasarkan Kompleksitas Wilayah

[Agung S. N., Diana F. dan Briantama Y. R.]

6.11 Transformasi Yogyakarta Menuju Smart City (Smart Tourism) Ditinjau dari Pengaruh Platform Iklan Berbasis Lokasi (Google Adword-Facebook Ads) untuk Digital Branding Industri Lokal : Studi Kasus dari Client Rakhmat Makmur Ecommerce Consulting

[Pinto Rakhmat].

6.12 Urgensi Transformasi Mata Pencaharian Sebagai Indikator Utama Pengembangan Wilayah dan Adaptasi Masyarakat Terhadap Perubahan Budaya Berbasis Edukasi di Kawasan Kampung Inggris, Kabupaten Kediri 
7.1 Analisis Kerentanan Banjir di DAS Brantas [Endang Savitri dan Rahardyan Nugroho Adi].

7.2 Analisis Mikromorfologi Tanah pada Posisi Topografi yang Berbeda (Studi Kasus di Perkebunan Tebu Pabrik Gula (PG) Camming, Sulawesi Selatan)

[Ahmad F. A., Risma N., dan Christianto L.]

7.3 Analisis Spasial Kerawanan Gempa Bumi Berbasis SIG dan PJ dalam Upaya Mitigasi Bencana

[Alwin dan Dinda D. N]

7.4 Identifikasi Tropical Frost Sebagai Bencana Hidrometeorologis di Dataran Tinggi Dieng

[Emilya N., Aditya P., dan Kania D. A.]

7.5 Inventarisasi Sumber Daya Alam di Kebun Raya Universitas Halu Oleo

[Anita I., Weka W., dan Sri R.]

7.6 Karakteristik Akuifer Wilayah Kepesisiran Parangtritis, Kabupaten Bantul [Sunarto, dkk.]

7.7 Pemanfaatan Citra Satelit Landsat 5 untuk Menganalisis Tanah Longsor (Studi Kasus: Tanah Longsor di Desa Paya Ateuk Aceh Selatan)

[Alamsyah Taher]

7.8 Pemanfaat Sistem Informasi Geografis untuk Pemetaan Risiko Bencana Gunung Api dari Aspek Sosial di Kabupaten Sleman

[Haikal Muhammad Ihsan, dkk.]

7.9 Pemetaan Kawasan Rawan Karlahut Berbasis Sistem Informasi Geografi dan Partisipasi Masyarakat di Bukit Batu

[Fakih Fauzan, dkk.]

7.10 Penentuan Lokasi PLTS dengan Citra Penginderaan Jauh untuk Pengelolaan Sumberdaya Alam Menggunakan Metode AHP (Studi Kasus Sulawesi Barat)

[Intan L., Isnia N. C. D., dan Zhafirah Z.]

7.11 Pengelolaan Kampung IT Berbasis WebGIS untuk Pemetaan Kawasan Kependudukan 
[Mohamad I. A., Rubiyanto M., dan Syahrial] ............................................... 916

7.12 Pola Spasial Fokus Keong Perantara Schistosomiasis Menggunakan Data Penginderaan Jauh dan Sistem Informasi Geografis di Dataran Tinggi Lindu, Sulawesi Tengah, Indonesia

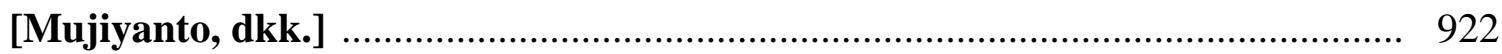

7.13 Studi Kemampuan Lahan di Desa Batu Putih Kecamatan Burau Kabupaten Luwu Timur

[Ramlah, Ibrahim A., dan Suprafta] ................................................................. 933

7.14 Teknologi Mitigasi dan Evakuasi Bahaya Marin

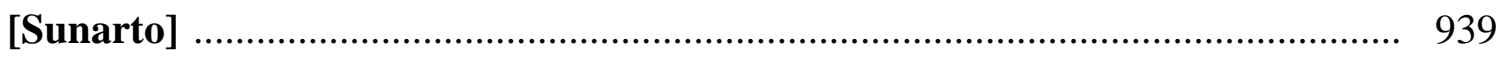




\title{
KARAKTERISTIK AKUIFER WILAYAH KEPESISIRAN PARANGTRITIS, KABUPATEN BANTUL
}

\author{
Sunarto $^{1}$, Ahmad Cahyadi ${ }^{1}$, Muh Aris Marfai ${ }^{1}$, Sigit Heru Murti ${ }^{2}$, \\ Hendy Fatchurohman ${ }^{3}$, Mukhamad Ngainul Malawani ${ }^{3}$ \\ ${ }^{1}$ Departemen Geografi Lingkungan, Fakultas Geografi, Universitas Gadjah Mada \\ ${ }^{2}$ Departemen Sains Informasi Geografi, Fakultas Geografi, Universitas Gadjah Mada \\ ${ }^{3}$ Magister Pengelolaan Pesisir dan Daerah Aliran Sungai (MPPDAS), Fakultas Geografi, \\ Universitas Gadjah Mada \\ Email: sunarto@ugm.ac.id, ahmadcahyadi@geo.ugm.ac.id
}

\begin{abstract}
ABSTRAK
Airtanah menjadi sumber air bersih yang sangat penting mengingat ketersediaanya adalah yang terbanyak setelah air tawar dalam bentuk es di kutub. Selain itu, kualitas airtanah seringkali lebih baik dibandingkan dengan sungai permukaan ataupun air hujan. Wilayah kepesisiran Parangtritis sejak dahulu dikenal sebagai lokasi wisata yang terus berkembang. Perkembangan tersebut tentunya akan mempengaruhi berbagai macam sumberdaya, di antaranya adalah airtanah. Penelitian ini bertujuan untuk mengetahui karakteristi akuifer di wilayah kepesisiran Parangtritis, Kabupaten Bantul. Metode yang digunakan adalah analisis data geolistrik. Data geolistrik tersebar di empat lokasi di lokasi kajian. Hasil analisis menunjukkan bahwa beberapa titik menunjukkan adanya zona interface, namun proses intrusi tidak intensif terjadi. Titik G1 menunjukkan adanya akuifer bebas dan akuifer tertekan akibat pengaruh dari Gunungapi Purba Parangtritis. Selain itu, muka airtanah di lokasi kajian termasuk dangkal dan memiliki konduktivitas hidraulik dan transmisivitas yang tinggi, sehingga selain memiliki potensi airtanah yang besar, lokasi kajian juga memiliki potensi tercemar yang tinggi pula.
\end{abstract}

Kata Kunci: Airtanah, Akuifer, Geolistrik, Parangtritis, Wilayah Kepesisiran

\section{PENDAHULUAN}

Air tawar merupakan kebutuhan pokok manusia dalam menjalani kehidupannya (Cahyadi dkk., 2011). Air tawar di Bumi umumnya bersumber dari air permukaan (sungai, kanal, danau dan waduk) dan airtanah (Hasan et al., 2017). Sejumlah 97\% dari total air tawar yang ada di Bumi (selain air dalam bentuk es di kutub) berupa airtanah (Carlos et al., 2012). Selain memiliki jumlah yang lebih banyak di bandingkan air permukaan, airtanah umumnya memiliki kualitas yang lebih baik karena mengalami proses penyaringan, sulit tercemar karena tersimpan dalam akuifer, serta memiliki pergerakan yang lambat, sehingga saat musim kemarau jumlahnya masih dapat diandalkan untuk memenuhi kebutuhan air (Cahyadi, 2015; Cahyadi dkk., 2015a; 2015b).

Saat ini diperkirakan sekitar 50\% kebutuhan domestik seluruh dunia dipenuhi dengan memanfaatkan airtanah (Thangarajan, 2007). Lebih lanjut Thangarajan (2007) menyebutkan bahwa sekitar $43 \%$ kebutuhan air untuk irigasi juga dipenuhi dengan memanfaatkan airtanah. Jumlah tersebut kemungkinan akan terus bertambah mengingat jumlah penduduk semakin banyak dan macam aktivitas manusia yang membutuhkan air semakin beragam. Margat and van der Gun (2013) menyebutkan bahwa sekitar 50\% penduduk dunia bertempat tinggal di wilayah perkotaan dengan konsumsi air yang lebih banyak dibandingkan wilayah perdesaan. Fakta lainnya adalah bahwa 50\% megacity (kota dengan jumlah penduduk lebih dari 10 juta jiwa) yang ada di dunia sangat tergantung kepada penggunaan airtanah untuk memenuhi kebutuhan air bersih (Khadri, 2016). 
Jumlah yang sangat banyak dari airtanah tidak menjamin keberadaannya merata dalam ruang dan waktu. Cahyadi et.al. (2012) menyatakan bahwa permasalahan sumberdaya air, termasuk airtanah terdiri dari empat hal, yaitu (1) jumlah yang tidak cukup, (2) kualitas yang buruk, (3) sebaran spasial yang tidak merata dan (4) ketersediaannya tidak sepanjang waktu. Tingkat permasalahan tersebut sangat tergantung dengan karakteristik wilayah seperti kondisi akuifer, ekologi bentanglahan, neraca air dan aktivitas manusia. Oleh karenanya analisis potensi berupa kualitas dan kuantitas dalam ruang dan waktu menjadi sangat penting (Cahyadi, 2012; Cahyadi dkk., 2016; Cahyadi dan Hidayat, 2017).

Wilayah kepesisiran merupakan wilayah yang memiliki karakteristik akuifer yang khas. Akuifer wilayah kepesisiran memiliki kontak langsung dengan air asin pada zona interface. Kondisi demikian menyebabkan akuifer di wilayah kepesisiran memiliki kerawanan yang tinggi terhadap intrusi air laut (Cahyadi dkk., 2013; Cahyadi dan Tivianton, 2013; Cahyadi dkk., 2015c). Bobba (2007) menjelaskan bahwa sekitar 50\% pernduduk di dunia menempati wilayah yang terletak pada wilayah di antara garis pantai sampai dengan $80 \mathrm{~km}$ ke arah daratan. Jumlah tersebut semakin meningkat dan aktivitas yang membutuhkan air juga semakin beragam. Selain itu, ancaman perubahan iklim, pemanasan global dan kenaikan muka air laut menjadikan pengelolaan airtanah di wilayah kepesisiran di masa mendatang menjadi semakin penting dilakukan (HerreraPantoja and Hiscock, 2006; Cahyadi et.al. 2017).

Wilayah Kepesisiran Parangtritis yang berlokasi di Kabupaten Bantul merupakan salah satu wilayah yang terus mengalami perkembangan, baik dari sisi pembangunan fisik ataupun dari jumlah demografi. Jumlah penduduk di Desa Parangtritis terus mengalami kenaikan (Tabel 1) dengan jumlah penduduk sampai tahun 2015 adalah sejumlah 7.893 jiwa. Selain itu, jumlah wisatawan di wilayah kepesisiran parangtritis terus mengalami kenaikan sampai dengan $10,71 \%$ pada tahun 2016. Jumlah wisatawan tahun 2016 sejumlah 2,8 juta jiwa (Syambudi, 2017). Kondisi yang telah disebutkan di atas berpotensi menyebabkan semakin tingginya penggunaan airtanah yang menjadi sumber utama penyediaan air bersih di Wilayah Kepesisiran Parangtritis. Penelitian ini bertujuan untuk melakukan analisis karakteristik akuifer di Wilayah Kepesisiran Parangtritis. Penelitian ini sebagai kajian awal dalam rangka memberikan masukan bagi penelitian selanjutnya yang terkait dengan pengelolaan sumberdaya Wilayah Kepesisiran Parangtritis, khususnya terkait dengan pengelolaan sumberdaya airtanah.

Tabel 1. Jumlah Penduduk di Desa Parangtritis, Kecamatan Kretek, Kabupaten Bantul

\begin{tabular}{cccc}
\hline \multirow{2}{*}{ Tahun } & \multicolumn{2}{c}{ Jenis Kelamin } & \multirow{2}{*}{ Jumlah Penduduk } \\
\cline { 2 - 3 } & Laki-laki & Perempuan & \\
\hline 2011 & 3.656 & 3.905 & 7.561 \\
\hline 2012 & 3.697 & 3.956 & 7.653 \\
\hline 2013 & 3.750 & 4.003 & 7.753 \\
\hline 2014 & 3.806 & 4.049 & 7.855 \\
\hline 2015 & 3.816 & 4.077 & 7.893 \\
\hline \multicolumn{3}{c}{ Sumber: http://desaparangtritis.com/demografi/ }
\end{tabular}

\section{METODE}

Penelitian ini dilakukan di Wilayah kepesisiran Parangtritis. Secara administrasi wilayah kajian terletak di Desa Parangtritis, Kecamatan Kretek, Kabupaten Bantul, Daerah Istimewa Yogyakarta (Gambar 1). Secara astronomis wilayah kajian menempati lokasi pada $420573 \mathrm{mT}$ sampai dengan $427342 \mathrm{mT}$ dan $9114468 \mathrm{mU}$ sampai dengan $9112434 \mathrm{mU}$. Wilayah ini secara geomorfologi menempati bentuklahan asal proses marin dan aeolian. 
Data yang digunakan dalam penelitian ini terdiri dari data akuisisi karakteristik akuifer dengan geolistrik, peta dan deskripsi peta geologi wilayah kajian serta refensi dari penilitian terdahulu. Pengukuran geolistrik dilakukan pada empat lokasi pengukuran (Gambar 1). Pengukuran geolistrik dilakukan dengan metode Vertical Electrical Sounding (VES), konfigurasi Schlumberger (Gambar 2). Pemilihan metode VES disebabkan karena metode ini cocok untuk menganalisis karakter akuifer secara vertikal dan memungkinkan dilakukannya analisis untuk akuifer yang tebal (Purnama dkk., 2013a; Haque et al., 2014).

Analisis data dilakukan dengan mengolah hasil pengukuran geolistrik dengan menggunakan software IP2WIN. Data hasil pencatatan di-input kemudian dilakukan inversi untuk menentukan nilai hambatan jenis material pada lokasi pengukuran. Interpretasi dilakukan berdasarkan Gambar 3 untuk membuat data log, sehingga dapat dianalisis karakteristik akuifer yang meliputi material, jenis akuifer dan prediksi nilai konduktivitas hidraulik.

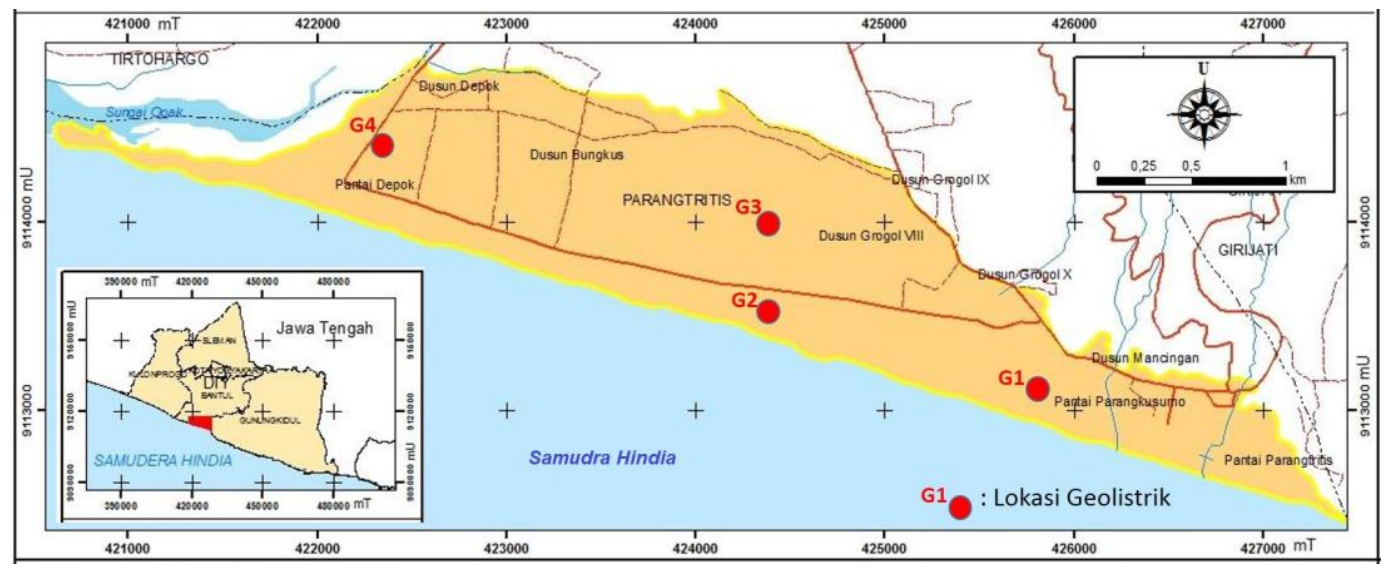

Gambar 1. Peta Wilayah Kajian dan Lokasi Pengukuran Geolistrik

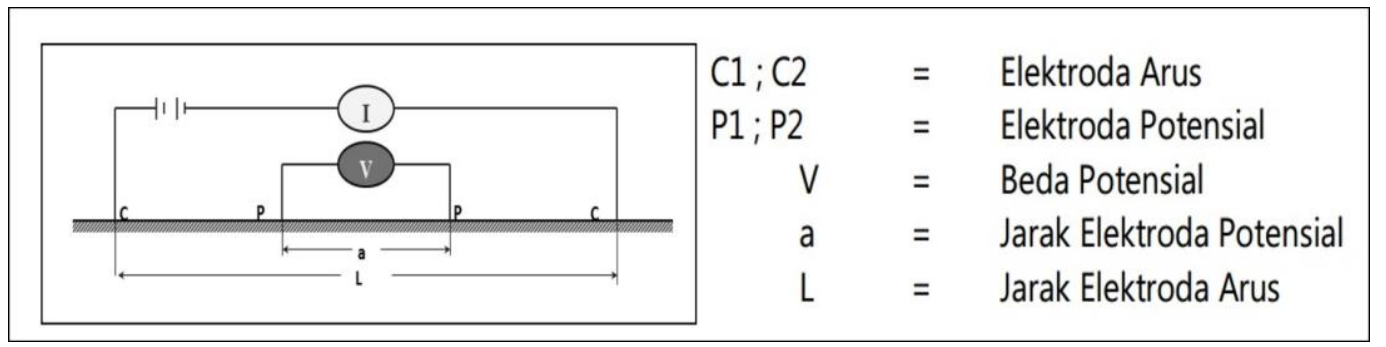

Gambar 2. Rangkaian Elektroda pada Geolistrik Metode VES dengan Konfigurasi Schlumberger (Purnama dkk., 2013b)

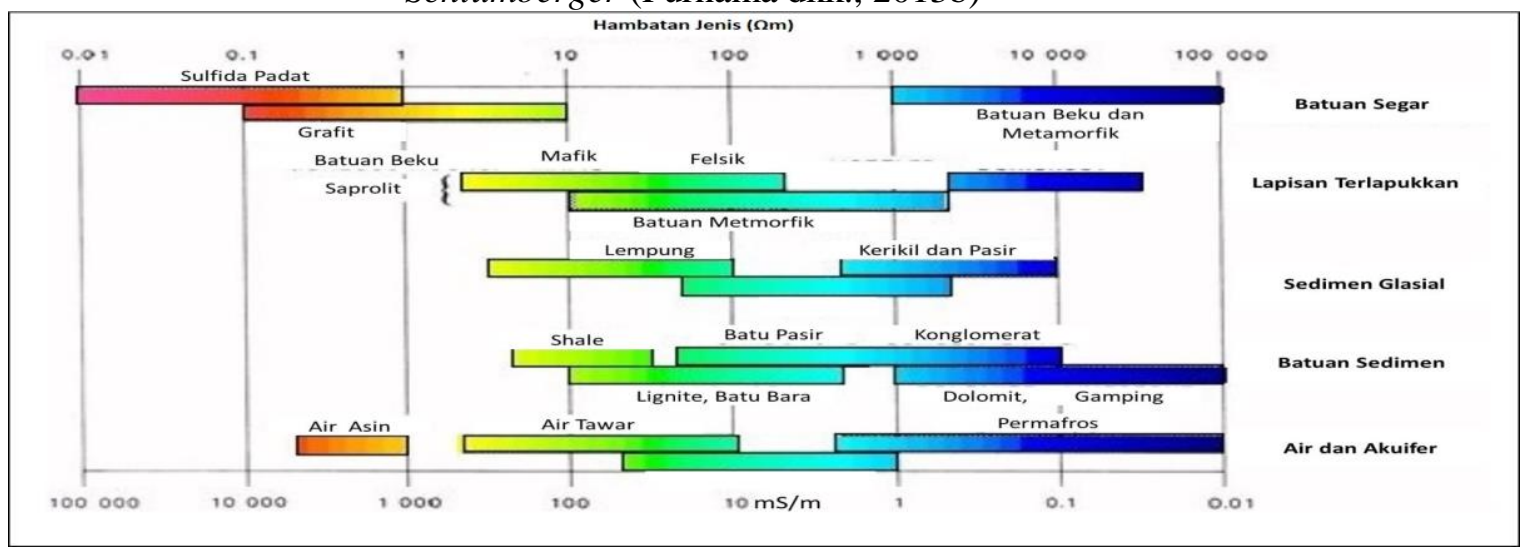

Gambar 3. Karakteristik Nilai Hambatan Jenis Berbagai Material (Janos, 2009)

Seminar Nasional Geografi 2017 - Program Studi S2 Geografi, Fakultas Geografi, UGM | 870 


\section{HASIL DAN PEMBAHASAN}

Raharjo dkk., (2005) dalam buku lampiran Peta Geologi terbitan Badan Geologi Lembar Jawa pada skala 1:100.000 menyebutkan wilayah kajian memiliki material yang diklasifikasikan dalam alluvium kuarter (Qa). Material penyusun dari alluvium di lokasi kajian terdiri dari material dengan ukuran butir kerakal, pasir, lanau, dan lempung . Meskipun demikian, hasil kajian di lapangan menunjukkan secara umum material di lokasi kajian didominasi oleh material bertekstur pasir yang halus sampai dengan kasar. Secara geomorfologi, wilayah kajian meliputi bentuklahan yang dikontrol oleh aktivitas marin dan Aeolian.

Dalam tinjauan pengelolaan airtanah, lokasi kajian termasuk dalam Cekungan Airtanah Yogyakarta Sleman. Cekungan airtanah ini membentang mulai dari Gunungapi Merapi sampai dengan wilayah kepesisiran di Kabupaten Bantul. Meskipun demikian, lokasi kajian memiliki karteristik unik, di mana wilayah ini merupakan satu-satunya wilayah kepesisiran di Kabupaten Bantul yang memiliki sistem airtanah yang terlepas dari sistem airtanah Gunungapi Merapi. Santosa dan Adji (2014) menyebutkan bahwa lokasi kajian merupakan endapan material yang diendapkan oleh proses marin dan aeolian yang berada di atas Formasi Litoral Wates (Gambar 4), sehingga tidak secara langsung terkait dengan sistem akuifer dari Gunungapi Merapi. Selain itu, pembentukan topografi gumuk pasir telah menyebabkan aliran airtanah di lokasi kajian dikontrol oleh topografi gumuk pasi tersebut.

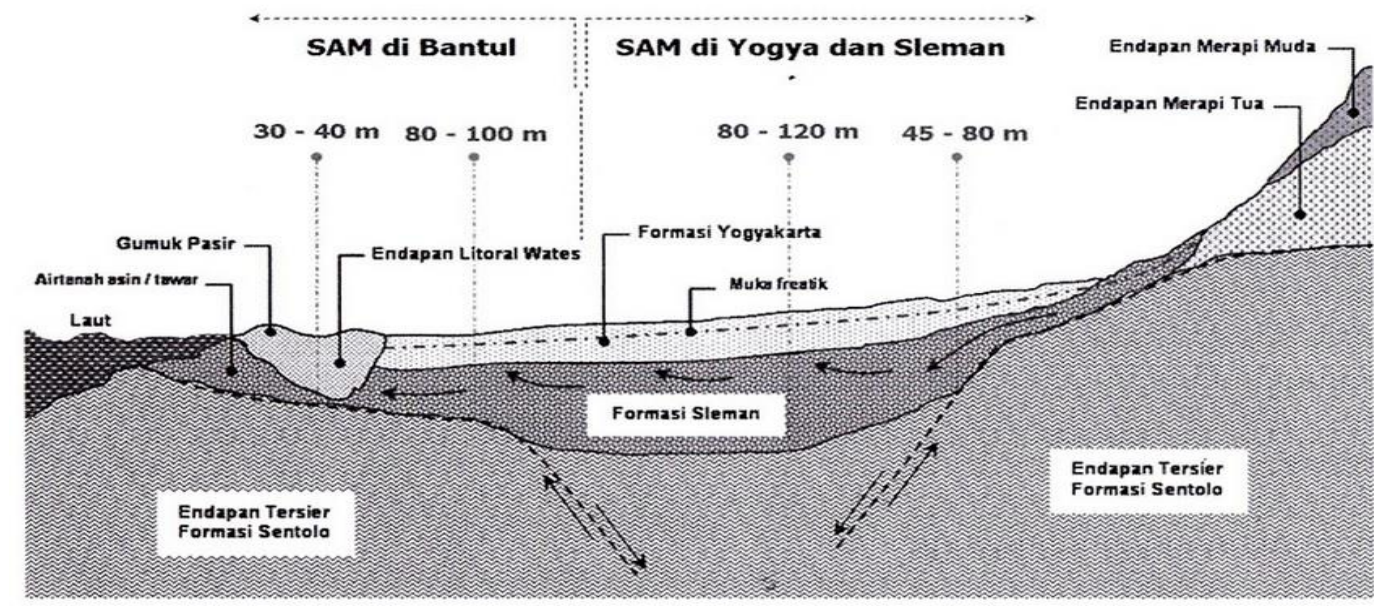

Gambar 4. Kedudukan Akuifer di Gumuk Pasir dalam Cekungan Airtanah Yogyakarta-

Sleman (Santosa dan Adji, 2014)

Hasil analisis terhadap hasil akuisisi data geolistrik di titik G1 ditampilkan dalam Gambar 5. Berdasarkan gambar tersebut diketahui bahwa pada titik satu terdapat dua lapisan akuifer, yaitu lapisan akuifer bebas (kedalaman $0-8$ meter) dan lapisan akuifer tertekan (kedalaman 8 - 17 meter). Lapisan batuan beku yang diduga adalah lava tidak lepas dari keberadaan Gunungapi Purba Parangtritis yang berada di sebelah utara lokasi kajian (Hartono, 2000; Hartono dan Bronto, 2007). Singkapan lava andesitik-basaltik yang dapat ditemui di sekitar lokasi pengukuran adalah pada tebing di sekitar Parangwedang, Makam Syekh Maulana Maghribi dan Cepuri Parangkusumo. Zona interface yang merupakan pertemuan air tawar dan air asin terdeteksi pada kedalaman 150 - 160 meter. 


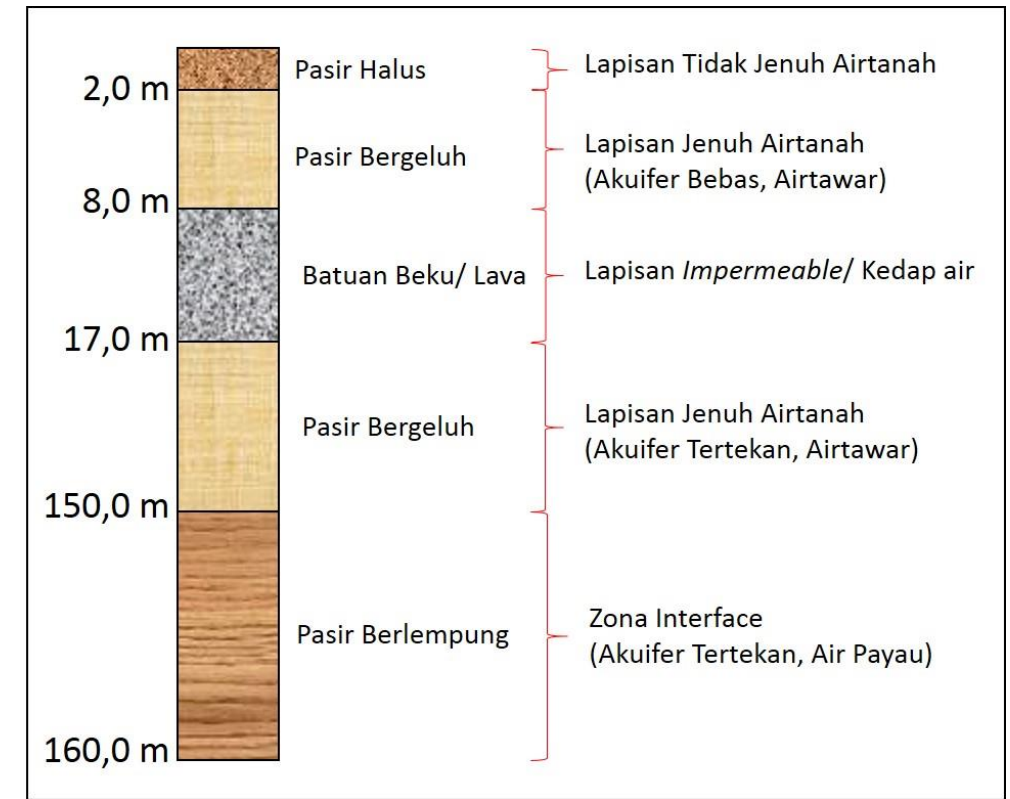

Gambar 5. Hasil Interpretasi Geolistrik pada Titik Pengukuran G1

Analisis terhadap hasil akuisisi data di titik G2 (Gambar 6), G3 (Gambar 7) dan G4 (Gambar 8) cukup berbeda dengan titik G1. Analisis pada ketiga lokasi tersebut tidak menunjukkan adanya nilai hambatan jenis batuan yang besar (diidentifikasi sebagai batuan beku). Zona interface ditemukan pada titik G2 yang terletak di dekat bentuklahan beting gisik di dekat pantai. Hasil interpretasi pada titik G3 dan G4 tidak mendeteksi zona interface. Hal ini menunjukkan bahwa proses intrusi air laut tidak terjadi secara intensif di lokasi kajian.

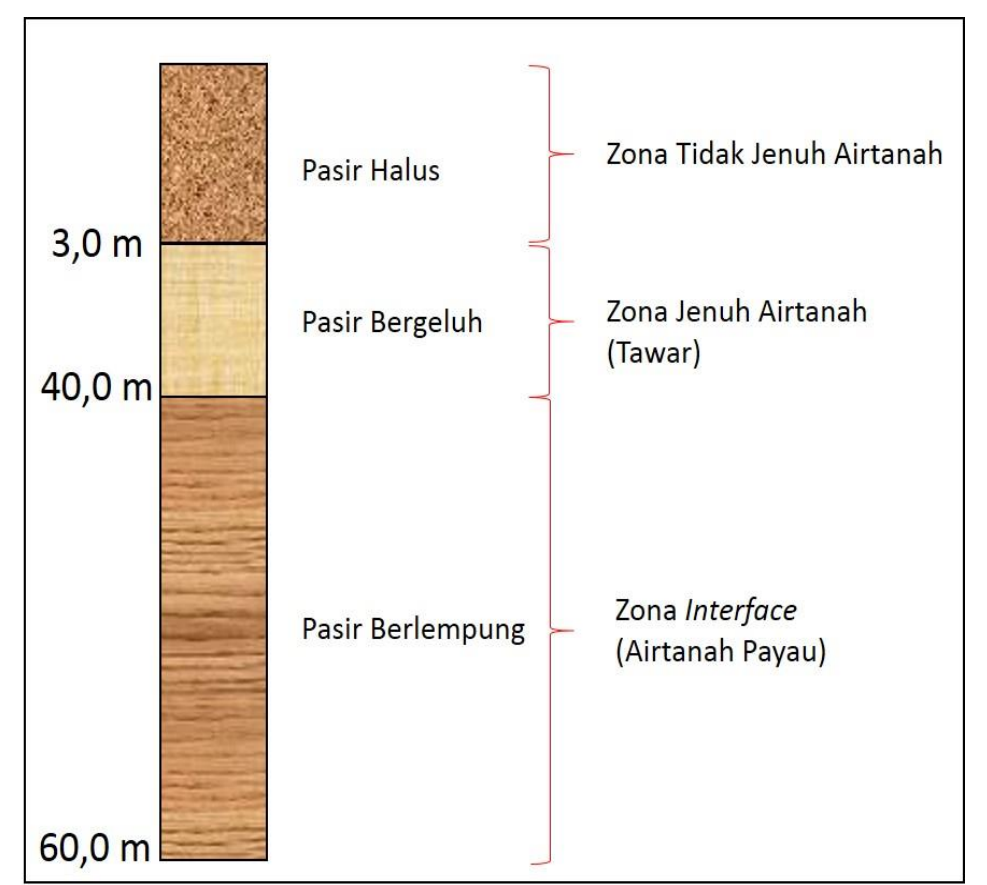

Gambar 6. Hasil Interpretasi Geolistrik pada Titik Pengukuran G2 


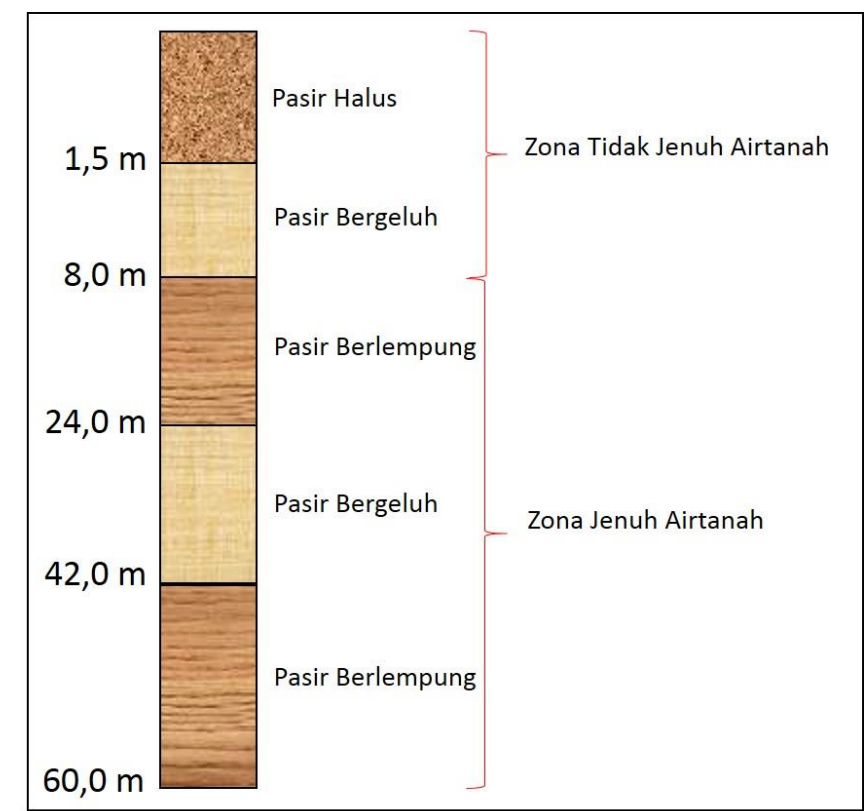

Gambar 7. Hasil Interpretasi Geolistrik pada Titik Pengukuran G3

Dominasi material pasir halus pada bagian atas akuifer bebas, khususnya pada zona tidak jenuh air menyebabkan wilayah kajian memiliki kerentanan airtanah yang cukup tinggi. Hal ini mengharuskan pengelolaan airtanah yang salah satunya menangani masalah permbuangan limbah cair yang dihasilkan oleh proses domestik dan aktivitas pariwisata yang ada di lokasi kajian. Hal ini untuk menjamin baiknya kualitas airtanah di lokasi kajian.

Kajian yang dilakukan oleh Putri (2008) menunjukkan bahwa nilai konduktivitas hidraulik (K) di lokasi kajian adalah antara $1,98 \mathrm{~m} /$ hari sampai dengan $16,58 \mathrm{~m} / \mathrm{hari}$. Nilai ini tergolong tinggi. Hasil lainnya menunjukkan bahwa nilai transmisivitas (T) akuifer di lokasi kajian memiliki nilai $82,9 \mathrm{~m}^{2} /$ hari sampai dengan $122,76 \mathrm{~m}^{2} /$ hari. Nilai $\mathrm{K}$ dan $\mathrm{T}$ yang tinggi akan menyebabkan kerentanan airatanh terhadap pencemaran akan tinggi.

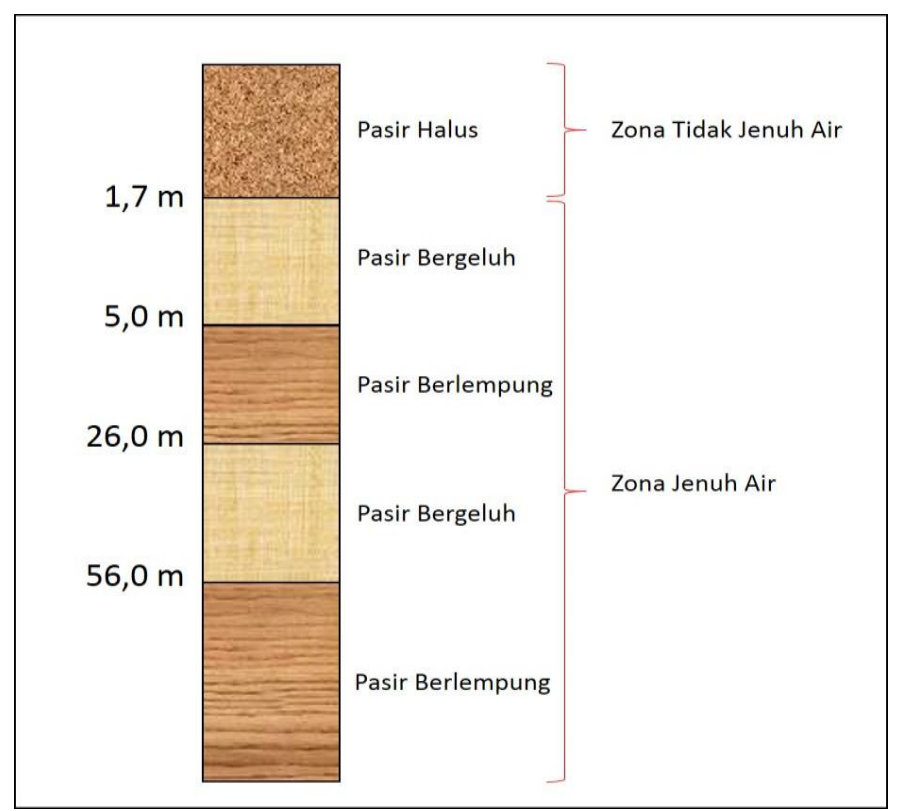

Gambar 8. Hasil Interpretasi Geolistrik pada Titik Pengukuran G4

Seminar Nasional Geografi 2017 - Program Studi S2 Geografi, Fakultas Geografi, UGM | 873 


\section{KESIMPULAN}

Hasil analisis menunjukkan material penyusun akuifer di lokasi kajian didominasi oleh material dengan tekstur pasir bergeluh dan pasir berlempung. Akuifer pada bagian timur terdiri dari lapisan akuifer bebas pada kedalaman $0-8$ meter dan akuifer tertekan pada kedalaman 17 - 150 meter. Zona interface ditemukan pada titik G1 dan G2 yang terletak di dekat pantai. Tidak teridentifikasinya zona interface pada titik G3 dan G4 menunjukkan tidak intensifnya proses intrusi air laut di lokasi kajian. Nilai K dan $\mathrm{T}$ yang tinggi di lokasi kajian menunjukkan potensi airtanah yang tinggi, namun di sisi yang lain memiliki kerentanan airtanah yang tinggi pula.

\section{UCAPAN TERIMAKASIH}

Penelitian ini merupakan bagian dari Hibah dari Kementerian Riset, Teknologi dan Pendidikan Tinggi melalui skema Program INSINAS Riset Pratama Kemitraan Gelombang II dengan Judul "Sistem Informasi Spasial Kemaritiman dan Potensi Kepesisiran untuk Pengembangan Eduwisata dan Konservasi Kawasan Kagungan dalem Gumuk Pasir dan Parangtritis Geomaritime Science Park”. Penulis mengucapkan terimakasi atas kesempatan dan pembiayaan yang diberikan untuk melakukan penelitian ini.

\section{Daftar Pustaka}

Anonim. 2016. Demografi Desa Parangtritis. Diakses dari http://desaparangtritis.com/demografi/

Cahyadi, A., Priadmodjo, A. and Yananto, A. 2011. Criticizing The Conventional Paradigm of Urban Drainage. Proceeding The 3rd International Graduated Student Conference on Indonesia. Yogyakarta: Sekolah Pascasarjana Universitas Gadjah Mada.

Cahyadi, A. 2012. Permasalahan Sumberdaya Air di Pulau Karang Sangat Kecil (Studi Kasus di Pulau Pramuka, Kabupaten Kepulauan Seribu, DKI Jakarta). Prosiding Seminar Nasional Pengelolaan Sumberdaya Alam dan Lingkungan. Semarang: Program Studi Ilmu Lingkungan Universitas Diponegoro.

Cahyadi, A.; Hidayat, W. dan Wulandari. 2013. Adaptasi Masyarakat Terhadap Keterbatasan Sumberdaya Air di Pulau Pramuka, Kepulauan Seribu, DKI Jakarta. Jurnal Penelitian Kesejahteraan Sosial, 12 (2): 207 - 213.

Cahyadi, A. dan Tivianton, T.A. 2013. Persepsi Masyarakat Terhadap Pemanenan Air Hujan dan Dampaknya Terhadap Ketahanan Sumberdaya Air di Pulau Pramuka, Kepulauan Seribu, DKI Jakarta. dalam Marfai, M.A. dan Widyastuti, M. 2013. Pengelolaan Lingkungan Zamrud Khatulistiwa. Yogyakarta: Buku Pintal.

Cahyadi, A. 2015. Analisis Potensi Sumberdaya Air Pulau Koral Sangat Kecil (Studi Kasus di Pulau Koral Pramuka, Kabupaten Kepulauan Seribu, DKI Jakarta). Tesis. Yogyakarta: Magister Perencanaan Pengelolaan Pesisir dan Daerah Aliran Sungai (MPPDAS), Fakultas Geografi, Universitas Gadjah Mada.

Cahyadi, A.; Marfai, M.A.; Tivianton, T.A.; Wulandari dan Hidayat, W. 2015a. Menyelamatkan Masa Depan Pulau-Pulau Kecil Indonesia. Prosiding Sarasehan Nasional Geografi Tahun 2013. Yogyakarta: Fakultas Geografi Universitas Gadjah Mada.

Cahyadi, A.; Agniy, R.F. dan Suhana, S.N. 2015b. Karakterisasi Hidrogeokimia Airtanah untuk Analisis Genesis Airtanah di Pulau Koral Sangat Kecil. Prosiding Seminar Nasional Ke-1 dalam Pengelolaan Pesisir dan Daerah Aliran Sungai. Yogyakarta: Magister Perencanaan Pengelolaan Pesisir dan Daerah Aliran Sungai, Fakultas Geografi, Universitas Gadjah Mada.

Cahyadi, A.; Adji, T.N. dan Marfai, M.A. 2015c. Analisis Evolusi Hidrogeokimia Airtanah di Pulau Koral Pramuka, Kepulauan Seribu. Prosiding Seminar Nasional Geografi. Surakarta: Universitas Muhammadiyah Surakarta. 
Cahyadi, A.; Adji, T.N. dan Marfai, M.A. 2016. Uji Akurasi Aplikasi Electromagnetic Very Low Frequency (EM VLF) untuk Analisis Potensi Airtanah di Pulau Sangat Kecil. Prosiding Seminar Nasional Ke-2 dalam Pengelolaan Pesisir dan Daerah Aliran Sungai. Yogyakarta: Magister Perencanaan Pengelolaan Pesisir dan Daerah Aliran Sungai, Fakultas Geografi, Universitas Gadjah Mada.

Cahyadi, A. dan Hidayat, W. 2017. Analisis Karakteristik Hidrogeokimia Airtanah di Pulau Koral Panggang, Kepulauan Seribu, DKI. Jakarta. Jurnal Geografi, 9(2): 99-108.

Cahyadi, A.; Riyanto, I.A.; Wacano, D.; Adji, T.N. dan Marfai, M.A. 2017. Geomorphological Condition Analysis of Pramuka Cay, Kepulauan Seribu Regency, Jakarta, Indonesia. The Third International Seminar on Science and Technology. Yogyakarta: Universitas Gadjah Mada.

Carlos, M.O.; Werner, A.D.; Post, V.E.A.; Hutson, J.L.; Simmons, C.T. and Irvine, B.M. 2012. Groundwater Recharge to a Sedimentary Aquifer in the Topographically Closed Uley South Basin, South Australia. Hydrogeology Journal, 20: 61-72.

Haque, M.N.; Keramat, M. and Shahid, S. 2014. Groundwater Resource Evaluation in the Western Part of Kushtia District of Bangladesh Using Vertical Electrical Sounding Technique. ISH Journal of Hydraulic Engineering, 21(1): 97-110.

Hartono, G. 2000. Studi Gunung Api Tersier: Sebaran Pusat Erupsi dan Petrologi di Pegunungan Selatan Yogyakarta. Tesis. Bandung: Institut Teknologi Bandung.

Hartono, G. dan Bronto, S. 2007. Asal-usul Pembentukan Gunung Batur di Daerah Wediombo, Gunungkidul, Yogyakarta. Jurnal Geologi Indonesia, 2(3): 143-158.

Hasan, M.; Shang, Y.; Akhter, G. and Jin, W. 2017. Evaluation of Groundwater Suitability for Drinking and Irrigation Purposes in Toba Tek Singh District, Pakistan. Irrigation Drainage System Engineering, 6(1). DOI: 10.4172/2168-9768.1000185.

Herrera-Pantoja, M. and Hiscock, K.M. 2006. The Effects of Climate Change on Potential Groundwater Recharge in Great Britain. Hydrol. Process. DOI: 10.1002/hyp.6620

Janos, F. 2009. Mineral Exploration. Magyarorszag, Hungaria: Terv.

Khadri, S.F.R. and Pande, C. 2016. Ground Water Flow Modelling for Calibrating Steady State Using MODFLOW Software: a Case Study of Mahesh River Basin, India. Model. Earth. Syst. Environ, 2(1). 1-17.

Margat, J. dan van der Gun, J. 2013. Groundwater Around the World. Boca Raton: CRC Press.

Purnama, S., Febriarta., Cahyadi, A., Khakhim, N., Ismangil, L. dan Prihatno, H. 2013a. Analisis Karakteristik Akuifer Berdasarkan Pendugaan Geolistrik di Pesisir Kabupaten Cilacap Jawa Tengah. Jurnal Geografi, 11(22), 155 - 165.

Purnama, S., Cahyadi, A., Febriarta., Khakhim, N., dan Prihatno, H. 2013b. Identifikasi Airtanah Asin Berdasarkan Pendugaan Geolistrik di Pesisir Kota Cilacap Jawa Tengah. Geomedia, 11(2), $183-190$.

Putri, F.W. 2008. Potensi Airtanah di Desa Parangtritis Kecamatan Kretek, Kabupaten Bantul, DIY. Tesis. Yogyakarta. Program Studi Geografi, Sekolah Pascasarjana, Universitas Gadjah Mada.

Raharjo, W., Sukandarrumidi dan Rosidi, H.M.D. 1995. Peta Geologi Lembar Yogyakarta, Jawa Skala 1: 100.000. Bandung: Pusat Penelitian dan Pengembangan Geologi.

Santoso, D. 2002. Pengantar Teknik Geofisika. Bandung: Penerbit ITB.

Santosa, L.W. dan Adji, T.N. 2014. Karakteristik Akuifer dan Potensi Airtanah di Graben Bantul. Yogyakarta: Gadjah Mada University Press.

Syambudi, I.A. 2017. 2,8 Juta Wisatawan di 2016, Parangtritis Masih Idola. Solopos, 4 Januari 2017. Diakses di http://www.solopos.com/2017/01/04/wisata-bantul-28-juta-wisatawan-di2016-parangtritis-masih-idola-781599

Thangarajan, M. 2007. Groundwater: Resource Evaluation, Augmentation, Contamination, Restoration, Modeling and Management. Heidelberg, Germany: Springer. 

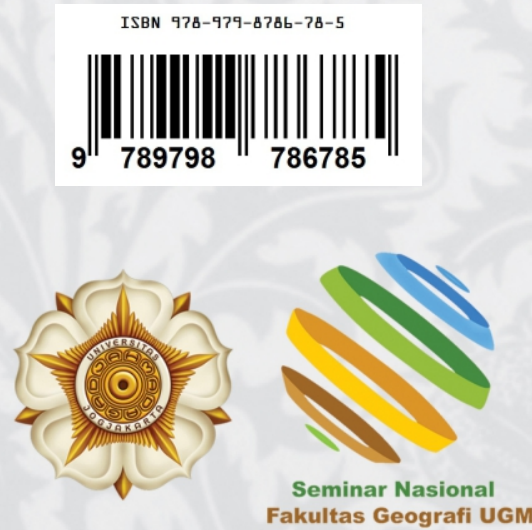

Fakultas Geografi Universitas Gadjah Mada

Skip Utara jln Kaliurang Bulaksumur, Yogyakarta 55281 phone +62-274-6492340 / 589595

Fax +62-274-589595

Email : geografi@geo.ugm.ac.id

Web : http:// semnas.geo.ugm.ac.id 